\title{
The Hausa Lexicographic Tradition
}

\author{
Roxana Ma Newman, International Programs and Department of \\ Linguistics (rmnewman@indiana.edu) and \\ Paul Newman, Department of Linguistics and West African Languages \\ Institute(pnxxpn@indiana.edu), Indiana University, Bloomington, \\ United States of America
}

\begin{abstract}
Hausa, a major language of West Africa, is one of the most widely studied languages of Sub-Saharan Africa. It has a rich lexicographic tradition dating back some two centuries. Since the first major vocabulary published in 1843 up to the present time, almost 60 lexicographic works - dictionaries, vocabularies, glossaries - have been published, in a range of metalanguages, from English to Hausa itself. This article traces the historical development of the major studies according to their type and function as general reference works, specialized works, pedagogical works, and terminological works. For each work, there is a general discussion of its size, accuracy of the phonological, lexical, and grammatical information, and the adequacy of its definitions and illustrative material. A complete list of the lexicographic works is included.
\end{abstract}

Keywords: ARABIC, BILINGUAL LEXICOGRAPHY, DIALECTAL VARIANTS, DICTIONARIES, ENGLISH, ETYMOLOGIES, FRENCH, GERMAN, GLOSSARIES, GRAMMATICAL CATEGORIES, HAUSA, LANGUAGE LEARNING, LOANWORDS, NEOLOGISMS, NIGER, NIGERIA, ORTHOGRAPHY, PHONETIC TRANSCRIPTION, PHONOLOGY, RUSSIAN, STANDARD DIALECT, STANDARDIZATION, TERMINOLOGY, VOCABULARIES, WEST AFRICA.

Opsomming: Die leksikografiese tradisie in Hausa. Hausa, ' $n$ belangrike taal van Wes-Afrika, is een van die tale van Afrika suid van die Sahara wat die wydste bestudeer word. Dit het 'n ryk leksikografiese tradisie wat ongeveer twee eeue oud is. Van die eerste groot woordeboek wat in 1843 gepubliseer is tot die hede is ongeveer 60 leksikografiese werke - woordeboeke, naamlyste, woordelyste - gepubliseer in 'n reeks metatale van Engels tot Hausa self. Hierdie artikel gaan die historiese ontwikkeling van die groter studies aan die hand van hulle tipe en funksie as algemene naslaanwerke, gespesialiseerde werke, opvoedkundige werke, en terminologiese werke na. Vir elke werk is daar ' $n$ algemene bespreking oor sy grootte, akkuraatheid van die fonologiese, leksikale en grammatikale inligting, en die toereikendheid van sy definisies en illustratiewe materiaal. ' $n$ Volledige lys van die leksikografiese werke is ingesluit.

Sleutelwoorde: AANLEER VAN TAAL, ARABIES, DIALEKTIESE VARIANTE, DUITS, ENGELS, ETIMOLOGIEË, FONETIESE TRANSKRIPSIE, FONOLOGIE, FRANS, GRAMMATIESE KATEGORIEË, HAUSA, LEENWOORDE, NAAMLYSTE, NEOLOGISMES, NIGER, NIGERIË, ORTOGRAFIE, RUSSIES, STANDAARDDIALEK, STANDAARDISERING, TERMINOLOGIE, TWEETALIGE LEKSIKOGRAFIE, WES-AFRIKA, WOORDEBOEKE, WOORDELYSTE.

\section{Introduction}

This article is a comprehensive survey of Hausa lexicography, comprising dictionaries, vocabularies, and glossaries. Hausa, a major language of West Africa, 
with an estimated 35-40 million speakers, is the largest member of the Chadic language family, which in turn belongs to the Afroasiatic phylum (P. Newman 1980a). It is the first language of ethnic Hausas and settled Fulanis in Hausaland, which stretches across the northern states of Nigeria and into southern Niger, and also of Hausa communities in the Sudan (Abu-Manga 1999). Hausa is spoken as a first language by scattered settlements throughout West Africa, and as a second language or lingua franca by millions of non-Hausas in northern Nigeria and in the northern parts of Benin, Togo, and Ghana. It is one of the three official national languages of Nigeria.

Due to its geographic spread, Hausa has a number of dialects, marked by differences in pronunciation, grammar, and vocabulary. The Hausa spoken in Kano State, Nigeria, is considered the standard dialect. This is the norm for the written language as well as the main dialect used by announcers in radio and television. Differences in modern vocabulary between the Hausa of Nigeria and that of Niger are due to their colonial histories, with heavy borrowings from English in the former and from French in the latter. Because most Hausa people are Muslim, a substantial portion of the lexicon reflects Arabic borrowings, especially with respect to religion, science, and government. There are also borrowings from neighboring African languages, especially Tuareg, Kanuri, Fulani (Fulfulde), and Yoruba.

Hausa has two writing systems. One orthography utilizes Arabic script, termed ajami, which has been employed at least since the beginning of the nineteenth century, and the other uses the Roman alphabet, termed boko, which was introduced by the British and the French at the beginning of the twentieth century. The current-day standard orthography uses Roman script with neither distinctions of vowel length nor of tone being marked.

Before examining the range of Hausa dictionaries that have been produced, it is important to provide some essential phonological and morphological information about the language itself so that one can appreciate some of the difficulties that Hausa lexicographers have had to face. This sketch, based on the reference grammar of P. Newman (2000), is limited to the standard Kano dialect.

Hausa has 25 consonants, leaving aside the labialized and palatalized (e.g., / kw/ and / ky/) consonants, namely /', b, 6, c, d, d, f, g, h, j, k, k, l, m, n, r, r, $\mathbf{s}, \mathbf{s h}, \mathbf{t}, \mathbf{t s}, \mathbf{w}, \mathbf{y}, \mathbf{y}, \mathbf{z} /$. (Note the orthographic use of /c/ to represent the affricate /ch/ as in English church, and the use of the apostrophe $/ /$ to represent glottal stop, this latter only being indicated in word-medial position.) Most of the consonants are similar to what are found in English and other European languages, but there are some significant differences.

First, Hausa has five "glottalized" consonants. Two of these, /6/ and /d/, are laryngealized/implosive stops. The third is an ejective velar $/ \mathbf{k} /$. There is also an apical ejective, orthographically represented as /ts/, whose pronunciation varies between [ $\left.\mathbf{s}^{\prime}\right],\left[\mathbf{t s}^{\prime}\right]$, and [ch'] depending on position and dialect. The 
last of the glottalized consonants is a laryngealized semivowel /'y/, a historically recent phoneme derived from / dy/ which is found only in a small number of lexemes of high frequency, e.g. 'yā 'daughter, small', 'yā'yā 'children'.

Second, Hausa has two phonemic /R/ sounds which are not distinguished in the standard orthography (P. Newman 1980b). One, which does not occur in word-final position, is a retroflex flap represented by $/ \mathbf{r} /$ e.g., barà 'servant'. The other, commonly represented in linguistic works by $/ \tilde{\mathbf{r}} /$, is an apical tap or trill, e.g., tar̃à 'nine'.

Third, most Hausa consonants can occur as geminates, indicated by double letters, e.g., gammō 'head pad', cf. gàmō 'meeting'.

Hausa has five vowels, a, e, i, o, $\mathbf{u}$, all of which can occur long or short, e.g., tà̀fī 'palm of hand' vs. tàfi 'go', and two diphthongs ai and au. In scholarly works, long vowels are either indicated by means of a macron $(\overline{\mathbf{a}})$ or by double vowels (aa). In closed syllables, only short, monophthongal vowels occur.

Hausa is a tone language with three distinctive tones, which are not indicated in standard orthography. These are high $(\mathrm{H})$, low $(\mathrm{L})$, and falling $(\mathrm{F})$. (There is no rising tone.) In modern Hausa linguistic scholarship, low is marked with a grave accent, e.g., à, falling is marked with a circumflex, e.g., â, and high tone is left unmarked, e.g., wùyā (L-H) 'trouble', fuskà (H-L) 'face', yârā (F-H) 'children'. (Most Hausa examples in this article use this tone/length notation, except when quoting examples drawn directly from works that are not phonologically marked.)

Hausa has two grammatical genders, masculine and feminine, distinguished in the singular only. Most feminine nouns end in /a/, e.g., rānā 'sun', but some masculine nouns do also, e.g., watà 'moon', and thus gender assignment has to be overtly marked. A striking and complex feature of Hausa is the multiplicity of noun and adjective plural formations involving suffixation, infixation, reduplication, and tone change. Although there are some correlations between the phonological shapes of the singulars and the choice of the plurals, this is essentially word-specific information that has to be lexically indicated. Moreover, many words allow alternative plural forms, e.g., dōkì 'horse', pl. dawākī, dàwà̀kai, and (less often) dōkunà.

There are two main morphogrammatical features of verbs that raise lexicographic problems. First, in certain syntactic environments, such as in a continuous tense or when following a modal verb (such as 'begin', 'repeat', 'quit', etc.), Hausa uses a "verbal noun" gerundive-type form rather than a finite verb, e.g., yā cìzāā 'He bit (it)', but yanà cìzồ 'He is biting', yā dainà cīzồ 'He quit biting'. The formation of verbal nouns from corresponding verbs is not regular or predictable and therefore needs to be noted in dictionary entries.

Second, Hausa verbs occur in morphologically productive forms termed "grades" (Parsons 1960), some of which are basic and some of which are derivational classes indicating "action totally done, action done away, action done towards or for the speaker, action affecting the subject (passive)", etc. Examples are: sàyā 'buy' (grade 2), sayề 'buy all' (grade 4), sayar̃ 'sell' (grade 5), sayō 'buy 
and bring' (grade 6), sàyu 'be bought' (grade 7). The grades present two lexicographic problems. First, not all verbs function in all grades, their occurrences being lexically specific. Moreover, although some grade forms (especially grades 2 and 3) tend to be more basic than others, this is not always the case with individual verbs, cf. dafầ 'cook' (grade 1 basic), kashè 'kill' (grade 4 basic), dāwō 'return' (grade 6 basic), jìtu 'get along' (grade 7 basic). Second, the meaning of a verb in some grade forms is fully predictable from the core meaning of the verb, but in others it is not. Thus the issue of how many and which verbs of this rich verbal system to include in a dictionary constitutes a vexing problem.

\section{Types of Hausa lexicographic works}

Hausa (and other Chadic languages) can boast of a long and distinguished tradition of linguistic scholarship going back some two centuries (see the general bibliographies of Baldi (1977) and P. Newman (1996), and the lexicographic overviews of R. M. Newman (1974) and Newman and Newman (1991)). As early as 1790, explorers and travellers in West and North Africa began to note down numerals and a few nouns in Hausa (see Hair 1967), culminating in the more extensive wordlists of Koelle (1854) and Barth (1862-1866). But if one had to pick one work from which to represent the beginning of modern Hausa lexicography, that would have to be the Hausa vocabulary of J. F. Schön (1843), a missionary who worked in West Africa for the Church Missionary Society. This productive lexicographic tradition continues to the present day, with the most recent dictionary being published in 1999. Over this period of 150+ years, 59 dictionaries, vocabularies, and glossaries have appeared, most of them bilingual. The metalanguages used in these works range from English, German, and French to Arabic, Italian, Japanese, and Russian. More recently, a few monolingual dictionaries have begun to appear, written by Hausa speakers themselves.

This survey categorizes these 59 works into four functional types, based on their primary purpose:

- Reference works: These are general dictionaries whose purpose and use are primarily scholarly. They are constructed on the current linguistic and analytical principles of their day. These include the major descriptive bilingual dictionaries.

- Specialized works: These are mostly glossaries or vocabularies devoted to restricted domains of the Hausa lexicon (crafts, fauna, idioms, music, etc.) or designed for special purposes, such as dialect or etymological studies.

- Pedagogical works: These are smaller bilingual (or trilingual) and monolingual dictionaries aimed at language learners, the focus being the basic vocabulary and expressions of every-day usage. 
- Terminological works: These are glossaries created to aid the expansion and development of Hausa vocabulary to meet the needs of a modern society. Standardization of loanwords and the creation of neologisms are explicit goals.

This article does not attempt to describe all of these works - a full list appears in the bibliography - but rather to comment on those which are considered by Hausa scholars to be milestones in the long development of Hausa lexicography. Each work reflects the progressive struggle of scholars and compilers to provide a better understanding of numerous aspects of Hausa, whether of pronunciation, orthography, tone, dialectal variation, etymological origins, grammatical categorization and grammatical relations, translation vs. explanatory equivalence, semantic relations between words, and neologisms and semantic extensions.

\section{Reference works}

James Frederick Schön, the father of Hausa studies, never actually set foot in Hausaland. He spent some fifteen years in Freetown, Sierra Leone, where he studied Hausa with freed slaves (Schön 1843). After returning to England, he continued his interest in Hausa, working with two speakers who had been brought back to Europe in the mid-1850s by the famous traveller Heinrich Barth (see Kirk-Greene and Newman 1971). One (Dorugu) was a native speaker, the other (Abbega) was a native Margi who spoke Hausa as a second language. With the help of Dorugu, Schön compiled the first large-scale lexicographical work on Hausa that can properly be called a dictionary (Schön 1876). This work consists of a Hausa-English section of some 3800 head entries and a slightly smaller English-Hausa section of about 3200 entries. In spite of its age, it is surprisingly modern in its approach and grammatical analysis, describing the major grammatical morphemes, pronoun classes, and derivational suffixes. Verbs are marked for transitivity, and nouns for plurality, though not for gender. The definitions are accurate and often describe the social situations in which words are used. More unfamiliar, however, are his phonological and orthographic notations, as Schön generally did not recognize glottalized or geminate consonants, and only occasionally marked long vowels by a stress mark. He was apparently unaware of the existence of tone in Hausa. Despite these weaknesses, Schön's orthography is still quite readable, with a basically phonemic alphabet and correct division of words.

A few years after Schön, the first vocabulary with French as the metalanguage appeared, compiled by J. M. Le Roux (1886) and published in Algiers. This 300-page work, which includes a 30-page grammatical introduction, is unusual in that the published volume is an entirely handwritten manuscript. It is the first lexicographic work on Hausa to include head entries written in both Arabic and Roman scripts. Although little is known about this work or the 
compiler, the fact that many entries are actually Arabic rather than Hausa indicates that it was likely based on the speech of a Hausa speaker living in North Africa who had an incomplete command of his native language. The work therefore remains more a curiosity in the history of Hausa lexicography than a work of scholarly significance.

The next period of lexicographic productivity took place around the beginning of the 20th century, when three substantial Hausa dictionaries appeared, quite independently of each other, each demonstrating significant advances in the understanding of Hausa. These dictionaries were compiled by English (Robinson 1899-1900), German (Mischlich 1906), and French scholars (Landeroin and Tilho 1909). Though inadequate from the point of view of phonological analysis, these early works contain useful grammatical information (such as gender and some noun plurals), short translation equivalents or reasonably accurate explanations, and some idiomatic expressions.

The Hausa-French dictionary of Landeroin and Tilho, published in Paris, is a substantial work, with a 172-page Hausa-French section followed by a 163page French-Hausa section, each containing about 6000 entries. While acknowledging the existence of Hausa written in Arabic script, the authors chose the Roman script as being more appropriate, especially for Europeans working in West Africa who wanted to learn Hausa. Their transcription recognizes the existence of the apical ejective, which they transcribed as /ts /, but not the other glottalized consonants. They were aware of some kind of distinction in vowel length for a small number of Hausa word pairs, which they attempted to mark with a "tonic accent", but failed to recognize that tonal differences were also involved. The major Hausa word classes are marked (nouns, verbs, adverbs, etc.). Grammatical gender was not recognized, possibly because they were working with a nonstandard Hausa dialect which did not make that distinction. Straightforward loanwords from Arabic were noted. Their transcriptions are surprisingly accurate in terms of word and morpheme boundaries, and their Hausa examples quite colloquial. The French-Hausa section is more properly a glossary or index, with few examples.

Charles H. Robinson was an Arabist and a member of an elite group of Hausa scholars in England who were dissatisfied with what they claimed was the overly "European" cast to Schön's works. After several trips to Hausaland, where he also collected manuscripts of Hausa written in Arabic script, Robinson published a two-volume dictionary in 1899/1900, which was revised three times in the following 25 years. Robinson's first two editions (1899/1900 and 1906) noted each Hausa headword in both Roman and Arabic scripts. Later editions dropped the ajami since most of his European readers did not know Arabic. He supplied Arabic roots for numerous Hausa words where he detected borrowing. Surprisingly, Robinson did not utilize vital phonemic information contained in ajami, where the differences between long and short vowels are clearly noted. By the time of his final and greatly expanded fourth edition (1925) of 11000 entries, he had solved the problem of the glottalized 
consonants / $\mathbf{6}, \mathbf{d}, \mathbf{k} /$, which he marked with a subscript dot under the normal consonants. However, he did not alphabetize them separately. Like Schön, Robinson acknowledged the existence of some type of tonal and/or accentual system, and used a diacritic to mark "short" syllables although this was very sporadic and unsystematic. But as he noted (19254: x), "The tones of pronunciation cannot be represented satisfactorily by any system of printing ..." In fact, the Hausa tonal system would not be fully recognized until the 1920s and not systematically analyzed and marked in Hausa dictionaries until the 1930s and 1940s. In general, Robinson's translation equivalents and definitions are accurate, with many entries having illustrative phrases and explanations. Some entries also have philosophical explanations of connotative and inferential meanings, as well as information of a more encyclopedic nature. Among his major innovations were a cross-referencing system to show the grammatical and semantic relations between words, the identification of major dialectal forms, and the stylistic use of the asterisk to indicate more esoteric scholarly loanwords from Arabic that were not yet fully incorporated into Hausa.

Two small volumes, Harris (1908) and Fletcher (1912), are collections of Hausa folklore, riddles, sayings, and customs, each accompanied by $1200-$ word vocabularies, excellent for their time. Harris's simple glossary contains a number of common idiomatic expressions. Fletcher's fuller work was intended as a supplement to the early editions of Robinson. It lists words missing in Robinson's first two editions, including a number of correctly analyzed compounds, as well as expanded and improved definitions. For example, whereas Robinson simply defines Hausa garaya as 'harp', Fletcher indicates 'a twostringed musical instrument with a long oval body, bigger than molo. The word is also used to describe the molon arna, an oblong instrument like a zithern ...' These additional entries and fuller explanations were incorporated, sometimes verbatim, into subsequent editions of Robinson.

Adam Mischlich's important Hausa-German dictionary (1906) was the result of years spent working as a missionary in a large dialectally diverse Hausa trading community in Kete-Krachi, Togo, complete with four mosques, a number of Koranic schools and many educated scholars. He published a grammar in 1902 and a dictionary in 1906, completed before he had seen Robinson's dictionary. This almost 700-page work contains approximately 7000 head entries written in both Roman and Arabic scripts. In contrast to Robinson, Mischlich incorporated the long/short vowel distinction noted in ajami into his Roman transcription, marking long vowels with a macron although this was not completely reliable. He treated the ejective /ts / as a unit phoneme which he alphabetized separately from $/ \mathbf{t} /$, a practice not subsequently followed by lexicographers until quite recently. The dictionary also noted dialectal forms and it was this research that Robinson incorporated in the last two editions of his own dictionary. Mischlich's dictionary reflects a deeper analysis of Hausa grammatical structure and understanding of derivational morphology, with many plurals and other related forms being included under the head entries. 
In the 1920s, the British colonial officer, F. W. Taylor, produced a series of grammars and vocabularies of Hausa and Fulani, the languages of the politically dominant elite in northern Nigeria. His trilingual Fulani-Hausa-English vocabulary of 3800 words (Taylor 1927) is more properly a specialized glossary than a general reference work. The vocabulary is organized according to an alphabetically organized mix of grammatical and semantic categories, e.g., abstract nouns; adjectives; animals (domestic); animals (wild); farming; horses; imperatives; verbs; war and hunting. Within each category, the words are alphabetized according to the English word. This specialized glossary is included in this section because it was the first Hausa lexicographic work to explicitly include the marking of tone. Taylor utilized a curious numerical system, which he first presented in his earlier Hausa grammar (Taylor 1923). Each word was followed by a series of numbers, e.g., nama 35 'meat' (= H-L); mata 13 'wife' (= L-H); and sabo 23 'new' (= H-H). Although the tone marking is far from reliable in its details, this work, along with his grammar, served to establish that Hausa was a tone language rather than a stress or accentual language, and thus set the stage for all subsequent lexicographic works.

The year 1934 saw the publication of what Hausa scholars universally acknowledge to be the masterwork of Hausa lexicography, the dictionary of G.P. Bargery (1934), a missionary linguist who devoted over 20 years in Nigeria to its compilation. It is a monumental volume of more than 1200 tightlypacked pages that has not only stood the test of time but will not likely be surpassed in the foreseeable future. It reflects a level of analytical sophistication and descriptive thoroughness that is rarely found in dictionaries or grammars of African or other "exotic" languages. It has justly been hailed as "one of the most outstanding linguistic achievements of the first half of the 20th century" (Green 1967: 59). The work is divided into two parts: the large Hausa-English section containing some 52000 head entries, of which about 39000 are main lexical entries and another 13000 derived and dialectal forms; and a concise English-Hausa index of about 5000 words.

For the first time, all Hausa head entries are written in phonologicallybased, (nearly) accurate transcriptions showing the glottalized consonants, the distinction between the two $/ \mathbf{R} / \mathrm{s}$, vowel length (except for final vowels with low tone), and tone. The major phonological breakthrough was his systematic analysis of the tonal structure of Hausa and the very phonetically accurate marking system that he devised, including perceptual differences that later turned out to be analyzable as intonational or subphonemic phenomena. His classification of verbs was also a major contribution, enabling him to identify derived forms and cross-reference them to their basic roots. Definitions are remarkably full and well illustrated, including numerous proverbs, epithets, and notes on the social and cultural contexts of usage. Many entries are written like paragraphs containing information more often relegated to an encyclopedia. Bargery also made efforts to group together semantically related words and synonyms. For example, under the entry for kātò 'huge', he lists about 330 
different words (some nouns, some ideophonic adjectives, some basic, some derived) that contain any semantically related notion of 'hugeness.'

Bargery was the first lexicographer to explicitly base his dictionary on the now standard dialect of Kano, Nigeria. Nevertheless he also included many dialectal forms and his work remains an important and accurate source for dialectal information. He also included much etymological information, noting borrowings not only from Arabic, but more recent ones from English and from other Nigerian languages.

Some 50 years later, in order to update Bargery's monumental work, Neil Skinner, a prolific lexicographer in his own right, published a supplement of 1500 entries which included neologisms, new borrowings from English and French, and semantic extensions of older terms (1985). In 1993, this supplement was incorporated in a new printing of Bargery by Ahmadu Bello University Press in Nigeria.

A second comprehensive Hausa dictionary that was modern in conception and impressive in scope appeared in 1949. It was that of R. C. Abraham, who served for two years as Bargery's assistant working primarily on Arabic origins and verb classification. Abraham, a British government anthropologist, was a truly remarkable and prolific scholar of African languages, who also compiled dictionaries and grammars of Amharic, Idoma, Somali, Tiv, and Yoruba (see Jaggar 1992). In some ways, his Hausa dictionary appears to be a revised edition of Bargery, but in other ways should be considered as an entirely new work. Abraham correctly phonemicized the tonal system and simplified its notation, marking only low and falling tones by diacritics under the vowel. While fully recognizing the distinctiveness of the two $/ R / s$, he unfortunately chose not to mark them in his dictionary, except in the case of a few minimal pairs. He developed a more elegant classification of the verbal system, which he used to identify each head verb in the dictionary, and included a great number of syntactic and semantic collocations to illustrate these verbs. An outstanding feature of Abraham's dictionary is the complete phonemic marking of every Hausa word in the book, in the examples as well as in the headwords, so that tone and vowel length distinctions are indicated throughout in context. (In Bargery, tone and vowel length are marked only in the headwords.)

Abraham also devoted great attention to grammatical analysis and information, not surprisingly, as he had also written two grammars of the language $(1934,1959)$. (By comparison, Bargery was one of the few Hausa lexicographers who did not also produce a grammar.) Abraham's presentation of related grammatical and morphological forms was much more compact than Bargery's, resulting in an estimated total of 35000 head entries. He excluded such predictable verbal derivational forms as intensives, past participles, statives, and regular verbal nouns. He also left out many nonstandard dialectal forms. In his definitions, Abraham was also more analytical, imposing a more narrowly linguistic interpretation of what properly should be included in a dictionary entry. His method was to let the various meanings and nuances of a 
word manifest themselves by illustrating the word in as many varied linguistic contexts as necessary, including proverbs and epithets. Bargery, on the other hand, often failed to include illustrative examples, rather choosing to describe the cultural and social contexts and referents associated with a word (see R. M. Newman (1992) for a discussion of their methodological differences).

In the 1960s, Russian scholars began to take an interest in Hausa and, acknowledging the earlier contributions of Bargery, Abraham, Mischlich, and Robinson, produced two comprehensive dictionaries. The Hausa-Russian volume of 460 pages containing 18000 entries was published in 1963 (Olderogge 1963), followed four years later by the Russian-Hausa 400-page volume of 22000 entries (Laptukhin and Kano 1967). These books incorporated a few linguistic advances over previous dictionaries. In the first volume, Hausa headwords beginning with glottalized consonants, as well as the phonemes /sh/ and /ts / represented by digraphs, are alphabetized as distinct letters in their own sections, and similarly within the word. (Although Bargery and Abraham had correctly noted the distinction between the three nonglottalized/glottalized consonant pairs $(\mathbf{b} / \mathbf{6}, \mathbf{d} / \mathbf{d}, \mathbf{k} / \mathbf{k})$, they chose not to have separate alphabetic sections for them.) Phonological information such as tone and vowel length are not provided. In terms of grammatical information, this is the first dictionary to attempt to include a system for marking a few derived "grade" suffixes for common verbs, as well as a codification of common plural suffixes for most nouns. The entries themselves are not particularly deep, giving many Russian translation equivalents but few examples of how they are used. The entries that are best illustrated are high frequency grammatical morphemes, the most common verbs, and idiomatic compounds. Because there is nothing on pronunciation and little on exemplification, the dictionary is clearly designed to be used for Russian speakers translating from written Hausa sources, and not for productive use. Similarly, the Russian-Hausa volume is designed to be used for reading comprehension by Hausas studying in Russia. Because many Russian words and concepts do not have exact Hausa translation equivalents, explanatory Hausa phrases are provided though these sometimes seem stilted and unnatural. Interestingly, there is some attempt to provide Hausa "equivalents" for modern Russian technical vocabulary by literal transliteration, so that radioactivity is rendered by the made-up Hausa word rediyoaktiviti, followed by a phrasal explanation.

The most recent scholarly reference work is the Hausa-French dictionary of Abdou Mijinguini (1994), a native Hausa linguist from Niger. His 500-page dictionary contains approximately 10000 head entries, well-illustrated with examples of colloquial usage. It is based largely on standard Niger Hausa, essentially the dialect of Damagaram rather than the standard Kano dialect that has dominated most previous lexicographic research. It represents a major step in the history of Hausa lexicography in that it is the work of an all-Hausa team of researchers, and it is printed in Niger. 
A number of innovative practices are found in this dictionary. Mijinguini adheres to the phonemic principle in the alphabetization of Hausa entries beginning with the digraphs /sh/ and /ts/, like the compilers of the Hausa-Russian dictionary. (By contrast, all of the contemporary pedagogical dictionaries - see following sections - follow the graphemic principle in the alphabetization of entries, with /sh/ being alphabetized within /s/ and /ts/ within /t/.) Regarding other phonological features, each headword in Mijinguini's dictionary is written in standard orthography, followed by a phonetic transcription marking tone, vowel length, and the distinction between the two $/ \mathbf{R} / \mathrm{s}$; this transcription is totally reliable.

The major departure from standard practice is in the choice of the form of the verb to use for the head entry. Since the earliest dictionaries, Hausa scholars have conventionally used the finite form of the verb occurring in phrasefinal position (with transitive verbs, when no object is expressed), e.g., yā kāmà 'he caught (something)'; àbín dà ya sàtā (with L-H tone) 'the thing that he stole'; yā tàfi 'he went'. This finite form occurs in all tenses/aspects except the continuous. For his dictionary, Mijinguini has chosen the gerundive or verbal noun form used in the continuous, corresponding roughly to -ing in English, e.g., kāmà̀wā 'catching'; sātà̀ 'stealing, theft' (with H-L tone); tàhiyà 'going'. He gives examples illustrating finite forms where appropriate, e.g., under tàhiyà 'going' will be found the sentence, har̃ sun tàhi? 'Have they gone already?' For Mijinguini, it seemed counterintuitive to give finite, syntactically contextual forms (equivalent to 'caught, stole, went') as head entries of verbs. Rather, his verbal noun forms are the closest equivalent in Hausa to nonconjugated, nonfinite verb forms that can be expressed out of context. It remains to be seen whether this innovative practice will be adopted by other Hausa lexicographers.

\section{Specialized works}

In addition to the general, all-purpose reference dictionaries, there have been a number of special-purpose lexicographic works, mostly dealing with specific or restricted semantic domains. An early study of this type, which focused on medical terminology, was published in 1915 by A.C. Parsons, father of the renowned British scholar F.W. Parsons, who, in the period after the Second World War, would establish himself as the world's leading expert on Hausa grammar.

A key study of botanical terminology was that of Dalziel (1916), a medical officer in the British colonial administration. This work included the scientific classification and Latin terminology for Hausa flora and has been a standard resource for all subsequent Hausa lexicographers. There are about 1300 entries, presented in Hausa alphabetical order with extensive English explanations describing the plants and providing information about their use. For example, Hausa garafuni (Momordica balsamina) is described as "'Balsam Apple'; a twiner 
of the cucumber family, with yellow flowers and orange-yellow tubercled fruits; used medicinally and in soup, and as a soap forming a viscid solution in water". The dictionary is accompanied by a ten-page index to genera according to the Latin terms and their common English names. Other studies providing Hausa terminology for trees and plants found in the area include Vischer (1936) for Nigeria, and, in more modern times, Lévy-Luxereau (1972) for Niger.

The Hausa-English dictionary of Ames and King (1972) provides a rich lexical study of Hausa musical terms presented in semantic and functional categories, namely, instruments (divided into types), parts of instruments, performers, patrons, musical occasions, and musical performances. There is an alphabetical Hausa index and an English-Hausa index. The book ends with ten pages of high quality photographs. It does not, however, contain pictures or drawings to illustrate the individual items being described.

The brief (18-page) study by Kafin-Hausa (1977) presents terms describing horses - these traditionally being of great importance in Hausa (upper class) culture - and associated items. Included are names for kinds and colors of horses, equine diseases, horse trappings, and different gaits. It is notable in that it is a monolingual Hausa-Hausa work directed primarily at a Hausa audience, although the information included is also of value for the international scholar.

Baldi (1989) is a presentation of almost 900 basic and cultural vocabulary items, numbered and organized into 21 semantic categories, including people, religion, education, animals, countries of the world, etc. Included are many modern concepts matched by the semantic extension of traditional Hausa vocabulary as well as by recently accepted new terminology. The headwords are given in five (!) languages, namely Italian, English, French, German, and Spanish, followed by Hausa equivalents written in standard orthography as well as accurate phonological transcription. The body of the glossary is followed by alphabetical indexes in the five European languages as well as Hausa that are cross-referenced to the numbered entries. There is also a brief index of technical Latin names for flora and fauna, a useful addition that is seldom provided in other works. This is a high-quality glossary that, unfortunately, has been generally neglected by Hausaists, perhaps because it is written in Italian.

Bross and Tela (1996) is a Hausa-English lexical study of crafts in the broadest sense of the term, i.e., it includes terms for objects, tools, verbs describing processes, as well as basic plants and materials used in preparing crafts. The volume is amply illustrated throughout with line drawings. The book is said to be a dialectal documentation - the basic research was carried out in areas other than that of standard Kano Hausa - but most of the entries are the same as one would find in standard Hausa.

Two dictionaries that truly focus on dialects other than on standard Kano Hausa are those of Matsushita (1991, 1993-1994). The first work is written in Japanese. It is a study of the dialect spoken in Sokoto in the western part of Hausaland. The entries are organized by topical and grammatical categories, e.g., body parts, animals, natural features, adjectives, verbs, etc. The headword 
(which is numbered) is provided in English and Japanese followed by the Hausa translation. These headwords are then accompanied by Hausa phrases and sentences with Japanese, but not English, translations. The book concludes with indexes containing all the Hausa and English words in alphabetical order cross-referenced to the headword numbers.

Matsushita's two-volume Hausa Dialect Vocabulary (1993-1994) is a computerized recompilation of material found in Bargery (1934). In Bargery, distinct dialectal variants were noted for specific items, both involving different words and variant pronunciations. There are some twenty different dialect labels covering geographical regions in Nigeria such as Daura, Sokoto, Zaria, etc., as well as features of Hausa spoken in Ghana. Dialectal forms were scattered throughout Bargery, wherever they might occur in their normal alphabetical place. Matsushita extracted all these labelled words from Bargery and collated them into separate dialect sections, in Hausa-English alphabetical order. Thus items marked (D.) are found in the Daura dialect section (pp. 15-58), those marked (S.) in the Sokoto dialect section (pp. 639-757), and so forth. Although the materials themselves are identical to the original Bargery entries, Matsushita's presentation makes lexical information about each dialect immediately accessible. It is a creative example of what computerization can accomplish.

The third work by Matsushita (1995-1996), also based on Bargery, is a reverse dictionary of Hausa, although a strange one. All the head entries in Bargery are presented in graphemically reverse order and alphabetized according to this order, followed by the word in its normal spelling. For example, the headword ABAS (p. 4) = Hausa saba 'be accustomed to', EFAS (p. 361) = Hausa safe 'in the morning', NITALAT (p. 645) = Hausa talatin 'thirty', and UBUD (p. 736) = Hausa dubu 'thousand'. All the entries are a maximum of one line long, so that if the Bargery entry is longer - as it inevitably is - it will only be partially reproduced and is often truncated midsentence or midword. The book contains no introduction and thus there is no explanation regarding how to use the work nor its supposed purpose. Nevertheless, for the linguist who might be interested in knowing something about the final rather than the initial phoneme(s) of words, the work can be useful. For example, it is commonly stated that Hausa words typically end in a vowel, which is indeed the norm. (In the reverse dictionary, words beginning (i.e., ending) in /a/ occupy some 324 pages.) It is thus surprising to discover that there are more than nine full pages of Hausa words ending in /s/, an inventory that no one could have been aware of before this reverse dictionary.

McIntyre and Meyer-Bahlburg's (1991) work falls somewhere between a specialized dictionary and a general dictionary. It is specialized in the sense that it is drawn almost exclusively from a specific corpus, mostly spoken materials from Hausa language radio programs broadcast by the Deutsche Welle (German World Service). However, the choice of words included does not constitute a coherent semantic set but rather represents a range of ordinary Hausa words randomly chosen, depending on the accident of what happened to occur in the texts consulted. There is thus no coherence as to what is included and 
what is not. For example, the work includes ten, but not seven, white, but not black, elephant, but not lion, and so on. The main entries are trilingual, in Hausa, English, and German. The Hausa headwords are given in normal orthography followed by phonologically accurate transcriptions indicating tone, vowel length, and the two $/ \mathbf{R} / \mathrm{s}$. Where the dictionary is excellent is in the examples of contemporary natural language and idiomatic usage, especially regarding modern political matters and world affairs. Part I, the Hausa-English-German section covers some 144 pages. Part II, which is of equal length, consists of an English-Hausa index and a German-Hausa index.

Dikko and Maccido (1991) is a specialized Hausa-Hausa dictionary of idioms, compounds, and closely-bound phrases, e.g., fuska biyu (lit. two faces) 'hypocrisy'; farin jini (lit. white blood) 'popularity'; sha kai (lit. drink head) 'to pester.' This excellent work contains some 4000 entries written in standard orthography and alphabetized by the first word in the compound expression. The literal meaning of the expressions is not provided, presumably because the book is designed for Hausa speakers who would already know the meaning of the constituent parts. But it is also a valuable resource for advanced language learners, who could benefit from a well-ordered list of idioms with their explanations.

Many of the Hausa reference dictionaries discussed earlier differ in the amount of information they offer regarding the etymologies of words. There are only two lexicographic works devoted exclusively to such a study. Baldi (1988) is a specialized etymological work comparing approximately 600 loanwords from Arabic found both in Hausa and in Swahili. The organization is by semantic category, e.g., nature, man as a physical being, man as a spiritual being, social organization, natural laws, plus the catch-all category, interjections and particles. Each Arabic word, given in Roman transliteration, is accompanied by the loanword in Hausa and Swahili, with indications of semantic divergence where appropriate. The main section is followed by alphabetical Hausa and Swahili indexes.

Skinner (1996) is the first full etymological dictionary of Hausa, the words having been selected on the basis of frequency of use. Loanwords, whether from English, French, Arabic, or some other African language, are clearly identified as such. In the case of Arabic, the exact form of the source word is usually provided. For nonloanwords, Skinner normally does not attempt to postulate a precise etymology; rather, he provides a relevant proto-Chadic reconstruction when available; otherwise he presents a large array of comparative citations. The hope is that subsequent scholars will be able to draw on these citations in order to determine the true cognate forms and the true etymological connections.

\section{Pedagogical works}

As early as the 19th century, wordlists and grammatical notes on Hausa were prepared as practical aids for Europeans in West Africa wanting to learn and 
use the language, these being primarily missionaries, explorers, or government agents and officials. In the 20th century, the range of learners expanded to include businessmen, researchers, university language students in the United States, Europe, and elsewhere, as well as international service and voluntary organizations such as the U.S. Peace Corps.

From the start, the target audiences of the early pedagogical works were primarily English, German, and French speakers, and this remains generally true up to the present. Among early efforts were the works of Delafosse (1901), Seidel (1906), and Haywood (1907), who included vocabularies of greater or lesser extent to accompany grammatical lessons intended for language learners. In Seidel, for example, separate grammatical sketches appear in German, French, and English, followed by a combined Hausa-English-German-French vocabulary of some 150 pages organized in semantic sets. By contrast, Miller (1907) is a small stand-alone glossary with both Hausa-English and EnglishHausa sections.

Practical (as well as other) dictionaries after the Second World War were able to draw on the tremendous advances in Hausa lexicographic scholarship represented by the major reference dictionaries of Bargery and Abraham, as described earlier. In this section, the discussion of pedagogical works is organized in terms of the language of the target learners, beginning with English.

The Hausa-English dictionary of Skinner (1959) is a small dictionary of 70 pages designed to be used as a handy reference tool. (The revised second edition of 1968 is truly pocket-sized in a $9 \times 12-\mathrm{cm}$ format.) It is written in standard Hausa orthography with many - though not all - words, especially homographs, having phonetic transcriptions indicating vowel length, but not tone. All headwords are identified for part of speech, and include essential information such as noun gender, plural formation, and verb transitivity/intransitivity.

Newman and Newman (1977) is a moderate-sized Hausa-English learners' / users' dictionary of 150 pages containing approximately 6000 head entries. Along with basic core vocabulary are incorporated many loanwords and neologisms that had entered the language over the previous half century. Linguistically it is totally up-to-date, marking the distinction between the two $/ \mathbf{R} / \mathrm{s}$, vowel length, and tones for all headwords. This is the first dictionary to mark the length of word-final vowels accurately, especially those with low tone. Both Bargery and Abraham consistently marked these low tone vowels as if they were short, as the length distinction in that environment can be phonetically quite reduced. A striking departure from all previous - and, as it has turned out, all subsequent - dictionaries was the decision to mark the short vowel (with a cedilla, e.g., a, ẹ, i, o, us) leaving the long vowels unmarked, as compared with the Bargery/Abraham tradition of only marking long vowels (with a macron). The decision was linguistically sound in that long vowels in Hausa are statistically more frequent than short. Almost all common nouns, for example, end in long vowels. Furthermore a number of derivational processes exist that are marked by vowel shortening, e.g., hannū 'hand'; but hannu 
'in/on the hand', gàjērē 'short', but Gàjēre 'Shorty' (nickname). However, the tradition in Hausa scholarship was too well established to be overcome, and this innovation was never accepted.

Published in Nigeria, this dictionary was designed primarily for nonHausa speakers, not only foreigners but more especially Nigerians with other first languages who want to learn Hausa, either formally in public schools or in practical settings. In the absence of an appropriate monolingual dictionary, native Hausa speakers have also used the dictionary as a guide to orthographic standardization and grammatical usage. Since first being published, the book has gone through some five printings.

Awde (1987) is, as its title indicates, an English-Hausa glossary divided into 43 mostly semantic categories (e.g., animal world; emotions, vices and virtues; herbs and spices; occupations; weather and elements; etc.), each with a selection of verbs appropriate to the category. There is also a small section of useful expressions. The English headwords are translated into several Hausa equivalents, with accurate phonological transcription, grammatical information on gender, plurals, and verb classes or "grades", but virtually no examples to illustrate the different equivalents.

Awde (1996) is a handy modern Hausa-English English-Hausa dictionary of about 18000 head entries of useful every-day vocabulary and short phrases, designed for both the non-Hausa person learning Hausa and the Hausa speaker learning English. Headwords or word compounds, fully marked for pronunciation, are matched with direct translation or short-phrase equivalents in the other language. Many entries contain numbered items and short examples, but this enumeration does not necessarily reflect semantic categorization. This practice is least helpful for the learner in the case of homophones, which are gathered together under a single entry rather than appearing as separate lexemes. For exampele, the Hausa homophone/homograph sâ is actually three separate words; it is a pronoun 'they', a noun 'bull', or a series of loosely related verbs 'cause, put (on), wear, fix, appoint'. On the English side, words like fire and watch have separate meanings as nouns or verbs, but they are not accordingly differentiated. In other respects, this dictionary is admirable for its choice of words, readability, and useful appendices.

R.M. Newman (1990) is the first large-scale dictionary (over 300 pages), going from a Western language to Hausa, that is designed to guide the learner in acquiring expressive, productive language competence. For each English entry, the aim is to provide the means for expressing the same idea in Hausa. The Hausa entries are not intended as literal translations but rather as conceptual, pragmatic equivalents. The book is rich in collocations and illustrative sentences. For example, under English 'tears', one finds the Hausa word hawàyē with the illustrative example, 'the tears ran down his cheeks', hawàyē sun zubō masà (lit. tears poured on him). But also, 'burst into tears', fashè dà kūkā (lit. break with crying) and 'be on the verge of tears', yi Kwâllā (lit. do tearfulness). Where different loanwords have entered Hausa in Nigeria (anglo- 
phone) versus Niger (francophone), both variants are presented, e.g., bucket bōkitì or sô (French seau). There are a number of important appendices, including a list of Hausa names, male and female, phonologically transcribed; the Hausa pronunciation of cities and states in Nigeria, Niger, and some international locations; the Hausa equivalents for countries outside of Nigeria and Niger; and the names for governmental organizations and international agencies. A brief grammatical sketch is also provided.

The dictionary provides essential grammatical information about Hausa equivalents that the learner should know to properly speak the language. Nouns are marked for grammatical gender and at least one common plural form. Verbs are overtly classified according to the Parsonian "grade" system (see Introduction above). Verbal nouns, namely, nominalized forms that are required when a verb is used in the progressive/continuous tense, are also included. Because of the richness of its exemplification, and the fullness of grammatical information provided, this work represents a major advance over previous English-Hausa dictionaries, whether viewed as scholarly or pedagogical.

Unlike the pedagogical works just described, which are intended primarily for non-Hausa speakers interested in learning Hausa, NORLA (1957), Skinner (1965), and Baki (1997), all published in Nigeria, are English-Hausa practical dictionaries designed to help Hausa speakers learn English. NORLA is a 335-page "manual of conversation" organized in dictionary format. The pronunciation of each English headword is provided, accompanied by a brief Hausa equivalent or equivalents written in standard orthography. The word is then amply illustrated with full English sentences followed by Hausa translations, generally going from literal to more metaphorical uses. For example, the entry for 'to die', Hausa rasu, mutu, contains the English sentences such as 'His son has died recently', Kwanan nan dansa ya rasu; 'The flowers have all died', Duk furen sun bushe (lit. All the flowers have dried up), and 'The fire died down', Gobarar ta lafa (lit. The conflagration has subsided). No information regarding part of speech or conjugational forms is given either for English or for Hausa.

Skinner (1965), a revised and illustrated edition of which appeared in 1978 , is similar in many ways to the NORLA volume. It differs in that the example sentences are greatly reduced so that it appears more like a dictionary rather than a conversation book. As with NORLA, pronunciation is provided for the English headwords, but otherwise lexicogrammatical information is not provided, apart from separate headwords for irregular past-tense verb forms such as 'bought', 'drove', 'went', cross-referenced to their infinitival forms. The book does include a brief introduction written in Hausa explaining the basics of English phonology and morphology.

Baki (1997) is a trilingual English-Arabic-Hausa dictionary of 235 pages, produced in Nigeria. The English headwords are accompanied by brief Arabic and Hausa translation equivalents written in the standard orthographies of those languages. No grammatical information or illustrative examples are 
included. According to the author, it is intended for Hausa beginners learning English and/or Arabic. However, in the absence of any other Arabic-Hausa dictionary, this could serve as a pocket guide for Arabic speakers learning Hausa.

Among practical dictionaries whose target users are German speakers, there are two modern ones. Herms (1987) is an attractively produced HausaGerman dictionary, closely modeled on Newman and Newman (1977), but containing more headwords (approximately 8500 as opposed to 6000 ). On the whole, the dictionaries of Herms and of Newman and Newman are of comparable quality, except that Herms, unfortunately, contains a number of small errors in the marking of tone and vowel length in the Hausa head entries.

McIntyre and Meyer-Bahlburg (1999), a more recent work, is a small German-Hausa vocabulary of 68 pages (plus appendices) aimed at German students. Although limited in size, and consisting mostly of short one- or twoword translations, the work is actually quite informative in that it includes essential grammatical information (e.g., grammatical gender, associated noun plurals, etc.), as well as common expressions and collocations. In addition, the Hausa examples are transcribed carefully and reliably.

French learners of Hausa now have a good moderate-sized dictionary with the well-produced French-Hausa work of Caron and Amfani (1997). A work similar in objective to R.M. Newman but with somewhat fewer headwords, approximately 3 700, it is intended both for French speakers learning Hausa and for Hausa speakers learning French. As such, it includes grammatical information and phonetic transcription for all the French headwords as well as the Hausa translations. Interestingly, the Hausa presented is that of the standard dialect of Nigeria, and the French loanwords used in Niger Hausa supplied by Newman are totally ignored. The book includes an extensive Hausa-French index of some 85 pages and a long 70-page introduction containing background information on Hausa classification and a grammatical sketch.

The trilingual Russian-Hausa-Yoruba dictionary (Laptukhin 1987) of 1200 entries is said to be expressly designed for Hausa and Yoruba speakers learning spoken Russian, with an introduction written in Russian and English. Phonetic transcriptions are therefore provided for each headword, but these are indicated in Cyrillic rather than in a more universal notation such as IPA (International Phonetic Alphabet). Declensions of Russian words, as well as verb perfective/imperfective stems, are listed after the head entry for the Hausa/Yoruba learner to consult. The entries themselves contain good examples and appear quite conversational. Sometimes one finds an overly literal Hausa translation of a Russian word, e.g., the word for blackboard is rendered literally as bakin allo 'black board' when more normal usage would simply be allo ('writing board'). Many photographs accompany the entries, but they are mainly of government buildings and monuments in Moscow! 
The final pedagogical dictionary discussed here is noteworthy in that it is the first monolingual Hausa dictionary ever published. Produced in Nigeria by an educator who trains teachers of Hausa, Garba (1990) is a modest first effort of some 2200 headwords, transcribed in standard orthography but with handwritten tones (low tone only) marked for each headword. This small dictionary is meant for upper primary school students and is admirable in its simplicity and design. Each word is labeled with its part-of-speech classification, these metalinguistic terms being explained in simple language in the short introduction. Nouns, which constitute the largest part of the list, are identified as masculine or feminine, with the most common plural forms given. Words are either defined by a synonym or a simple explanatory definition. Polysemic words have each meaning numbered and explained, although there are no examples of usage. A number of line drawings accompany many nouns. The book is a good first dictionary for the young native Hausa speaker, but could also be very useful to the nonnative learner looking for good conversational explanations in Hausa.

\section{Terminological works}

As a major world language, Hausa has been undergoing rapid modernization and lexical expansion to cope with the changing world. For many years, regular international broadcasts have been produced in Hausa by the British Broadcasting Corporation, the Voice of America, Deutsche Welle, and Radio Beijing, and more recently by other nations in Africa. The need for Hausa standardized terminology to express modern concepts, sociopolitical structures, and material goods is urgent, and has been recognized for years. Thus the fourth major type of Hausa lexicographic work discussed here consists of those terminological vocabularies and glossaries that have been published in Nigeria and Niger. They result from projects promoted by language planners and educators whose goals are to modernize and expand the Hausa lexicon to meet the needs of the modern world. Some of these works were individual efforts; others have been carried out or commissioned by governmental or pseudogovernmental bodies.

In Nigeria in the 1950s and 1960s, the Hausa Language Board, which was set up by the Northern Region House of Assembly in 1955 (see Kirk-Greene 1964), was the main organization focusing on language development and standardization. Pamphlets that they produced include Alphabetical List of Words Imported into Hausa (ca. 1958), Glossaries of Technical Terms (Bayanin Kalmomin da a ke Anfani da su a Ma'aikatu Iri Iri) (Explanations of Words Used in Various Work Places) (ca. 1959), and Vocabulary of Modern Political and Administrative Terms (1964). A pamphlet of a similar nature focusing on governmental terms (from English to Hausa) was prepared by the then Head of the Department of Local Government at the Institute of Administration (Campbell ca. 1958).

In more recent years, the responsibility for all indigenous Nigerian language matters has fallen to the Nigerian Educational Research and Development Council (NERDC). An important product of NERDC's efforts was the 
publication of A Glossary of English-Hausa Technical Terms in Language, Literature and Methodology (Muhammed 1990). The first half of the volume is an English to Hausa vocabulary organized by topic, e.g., linguistics, literary analysis, etc. The second half consists of a straight alphabetical Hausa to English vocabulary in which tone and vowel length are indicated for all the Hausa entries. The Quadrilingual Glossary of Legislative Terms (NERDC 1991) is an ambitious book aimed at expanding the lexicons of Nigeria's three official national languages, Hausa, Yoruba, and Igbo. It is a work of almost 300 pages containing over 10000 head entries, and is semantically much broader than the title would suggest. In addition to legislative and governmental terms, it also includes many words and expressions having to do with economy, education, health and medicine, sports, and the military. Each page consists of four columns for each language with the words being arranged in English alphabetical order.

In both of the NERDC books, the attempt is not to explain the English words or expressions, but rather to provide direct translation equivalents. In some cases, the Hausa equivalents represent established usage. But in many others, they have been created by the compilers themselves, working collaboratively with other native-speaker educators and linguists. Only time will tell whether the proposed neologisms (in Hausa, Yoruba, Igbo) will or will not be adopted and become part of these functioning languages.

Another terminological work is Jinju (1990), a trilingual Hausa-EnglishFrench presentation of Hausa vocabulary in the areas of science and technology. Sakkwato (1993) is a similar work (but without French included) focusing on the vocabulary of geography.

In Niger, the main government bodies promoting lexicographic work have been the Centre d'Études Linguistiques et Historiques par Tradition Orale (CELHTO) and the Institut National de Documentation de Recherche et d'Animation Pédagogiques. Mahamane (1982) is a listing of French words relating to scientific matters with simple one-word or short-phrase Hausa counterparts. Mijinguini (1983a) gives Hausa equivalents for French words describing history and geography, including flora and fauna and agricultural produce. Although the Hausa entries are usually simple translations, alternative forms and brief explanations are sometimes provided, thereby making this work particularly useful. Mijinguini (1983b) provides Hausa equivalents of French words concerning language and linguistics, again presented in straightforward French-Hausa alphabetical order. In these three vocabularies, the Hausa entries are given in the orthography that is now standard throughout Hausaland, both in Nigeria and in Niger, but the forms of words reflect the dialectal characteristics of northwest Hausa, e.g., 'plain (land)' hwangali, cf. Kano Hausa fangali; 'telephone' talho, cf. Kano Hausa tarho; 'hoe' kalmi, cf. Kano Hausa fatanya.

\section{Conclusion}

A number of themes recur throughout this description of the historical development of Hausa lexicography over the past two centuries: the increasingly 
accurate linguistic analysis of the language, especially its phonology and morphology; the increasing naturalness of definitions and the progressive inclusion of idiomatic usage and modern terminology; and the ever greater participation of native Hausa speakers as compilers of these works. Hausa has been one of the most extensively studied languages in Sub-Saharan Africa. This comprehensive guide to its rich lexicographic tradition attests to the vitality of Hausa and to its place as one of Africa's most important and influential languages.

\section{Bibliography}

\section{A. Hausa Dictionaries, Vocabularies, and Glossaries}

Abraham, R.C., and Mai Kano. 1949. Dictionary of the Hausa Language. London: Crown Agents for the Colonies. (2nd ed. with new introduction and second author's name omitted, London: University of London Press, 1962.)

Ames, David W., and Anthony V. King. 1972. Glossary of Hausa Music and its Social Contexts. Evanston: Northwestern University Press.

Awde, Nicholas. 1996. Hausa-English English-Hausa Dictionary. (Hippocrene Practical Dictionary.) New York: Hippocrene Books.

Awde, Nicholas, with Sa'idu Babura Ahmad and Malam Barau. 1987. "21st Century" Hausa: An English-Hausa Classified Wordlist. London: Centre for African Language Learning.

Baki, Alhaji Issah Alhassan. 1997. Modern Dictionary of English, Arabic and Hausa. / Kamus na Turanci da Larabci da Hausa. Zaria (Nigeria): Hudahuda Publishing Co.

Baldi, Sergio. 1988. A First Ethnolinguistic Comparison of Arabic Loanwords Common to Hausa and Swahili. (Supplement 57 to AION 48(4).) Naples: Istituto Universitario Orientale.

Baldi, Sergio. 1989. Manuale propedeutico di hausa con glossario e lessico concettuale di base. Naples: Istituto Universitario Orientale.

Bargery, G.P. 1934. A Hausa-English Dictionary and English-Hausa Vocabulary. London: Oxford University Press. (Reprint with supplement and new introduction by N. Skinner, Zaria: Ahmadu Bello University Press, 1993.)

Bross, Michael, and Ahmed Tela, with drawings by A. T. Sati Baba. 1996. Dictionary of Hausa Crafts: A Dialectal Documentation. (Westafrikanische Studien: Frankfurter Beiträge zur Sprachund Kulturgeschichte, 10.) Cologne: Rüdiger Köppe.

Campbell, M.J. ca. 1958. A Word List of Government and Local Government Terms (English-Hausa). Kaduna (Nigeria): Baraka Press.

Caron, Bernard, and Ahmed H. Amfani. 1997. Dictionnaire français-haoussa suivi d'un index haoussafrançais. Paris: Karthala.

Dalziel, J.M. 1916. A Hausa Botanical Vocabulary. London: T. Fisher Unwin.

Delafosse, Maurice. 1901. Manuel de langue haoussa ou Chrestomatie haoussa, précédé d'un abrégé de grammaire et suivi d'un vocabulaire. Paris: J. Maisonneuve.

Dikko, Inuwa, and Usman Maccido. 1991. Kamus na Adon Maganar Hausa (Dictionary of Hausa Idioms). Zaria (Nigeria): NNPC.

Fletcher, Ronald S. 1912. Hausa Sayings and Folklore, with a Vocabulary of New Words. London: Oxford University Press. 
Garba, Calvin Y. 1990. Kamus na Harshen Hausa (Dictionary of the Hausa Language). Ibadan (Nigeria): Evans Brothers.

Harris, Hermann G. 1908. Hausa Stories and Riddles with Notes on the Language, etc., and a Concise Hausa Dictionary. Weston-super-Mare: The Mendip Press.

Hausa Language Board. ca. 1958. Alphabetical List of Words Imported into Hausa. Kaduna (Nigeria): Baraka Press.

Hausa Language Board. ca. 1959. Glossaries of Technical Terms (Bayanin Kalmomin da a ke Anfani da su a Ma'aikatu Iri Iri (Explanations of Words Used in Various Work Places)). Kaduna (Nigeria): The Hausa Language Board, Ministry of Education, Northern Region.

Hausa Language Board. 1964. Vocabulary of Modern Political and Administrative Terms. Kaduna (Nigeria): Baraka Press.

Haywood, A.H.W. 1907. English-Hausa Vocabulary of Words in Everyday Use. London: Kegan Paul. (2nd ed. 1914.)

Herms, Irmtraud. 1987. Wörterbuch Hausa-Deutsch. Leipzig: VEB Verlag Enzyklopädie.

Jinju, Muhammadu Hambali. 1990. Garkuwar Hausa da Tafarkin Ci Gaba: Kalmomin Kimiyya da Ilimin Fasaha na Hausa (Hausa Scientific and Technological Words). Kaduna: Fisbas Media Services Publications.

Kafin-Hausa, Abdullahi Umar. 1977. Sunayen Dawaki da Kayan Hawa (Terms for Horses and Associated Accoutrements). Kano (Nigeria): CSNL, Bayero University.

Landeroin, M., and J. Tilho. 1909. Dictionnaire haoussa, comprenant haoussa-français et françaishaoussa. Paris: Émile Larose.

Laptukhin, Viktor V., and Ado Gwadabe Kano. 1967. Russko-xausa slovar'. Kamus na RashanciHausa (Russian-Hausa Dictionary). Moscow: Sovetskaja Enciklopedija.

Laptukhin, Viktor V. et al. 1987. Učebnyj russko-xausa-joruba slovar' (Student's Russian-HausaYoruba Dictionary). Moscow: Russkij Jazyk.

Le Roux, J.M. 1886. Essai de dictionnaire français-haoussa et haoussa-français. Algiers: Adolphe Jourdan.

Lévy-Luxereau, Anne. 1972. Étude ethno-zoologique du pays hausa en République du Niger. Paris: Société d'études ethno-zoologiques et ethno-botaniques.

Mahamane, Issoufou. 1982. Lexique scientifique français-hausa. Niamey: Centre d'Études Linguistiques et Historiques par Tradition Orale.

Matsushita, Shuji. 1991. A Basic Vocabulary of the Sokoto Hausa (Northern Nigeria). (Asian and African Lexicons, 22.) Tokyo: Tokyo University of Foreign Studies, Institute for the Study of Languages and Cultures of Asia and Africa.

Matsushita, Shuji. 1993-1994. Bargery Toolbox 1-2 (Based on Rev. G.P. Bargery's A Hausa-English Dictionary): Hausa Dialect Vocabulary. 2 vols. Tokyo: Tokyo University of Foreign Studies, Institute for the Study of Languages and Cultures of Asia and Africa.

Matsushita, Shuji. 1995-1996. Bargery Toolbox 3-4 (Based on Rev. G.P. Bargery's A Hausa-English Dictionary): Hausa / asuaH: Back to Front, Volume 1 (A-E); Volume 2. (F-Z). Tokyo: Tokyo University of Foreign Studies, Institute for the Study of Languages and Cultures of Asia and Africa.

McIntyre, J.A., and Hilke Meyer-Bahlburg, assisted by Ahmed Tijani Lawal. 1991. Hausa in the Media: A Lexical Guide. Hamburg: Buske.

McIntyre, J.A., and Hilke Meyer-Bahlburg. 1999. Arbeitsvokabular Deutsch-Haussa. (Arbeitsmaterialien zur Afrikanistik, 1.) Hamburg: LIT. 
Mijinguini, Abdou. 1983a. Petit lexique français-hausa d'histoire et de géographie. (Études et Documents, 165.) Niamey (Niger): Institut National de Documentation de Recherche et d'Animation Pédagogiques.

Mijinguini, Abdou. 1983b. Vocabulaire technique des sciences du langage (français-hausa). Niamey: CELHTO.

Mijinguini, Abdou. 1994. Karamin Kamus na Hausa zuwa Faransanci (Concise Dictionary of Hausa and French). Niamey (Niger): SP-CNRE/PS-UNESCO.

Miller, Walter R. 1907. Hausa and English Vocabulary. Lagos: C.M.S. Bookshop. (2nd ed. 1930.)

Mischlich, Adam. 1906. Wörterbuch der Hausasprache. (Lehrbücher des Seminars für Orientalische Sprachen, 20.) Berlin: G. Dietrich Reimer.

Muhammed, D. (Ed.). 1990. Hausa Metalanguage. Kamus na Ke6a66un Kalmomi). Vol 1: A Glossary of English-Hausa Technical Terms in Language, Literature and Methodology. Ibadan (Nigeria): University Press.

NERDC. 1991. Quadrilingual Glossary of Legislative Terms (English, Hausa, Igbo, Yoruba). Lagos: Nigerian Educational Research and Development Council.

Newman, Paul, and Roxana Ma Newman. 1977. Modern Hausa-English Dictionary (Sabon Kamus na Hausa zuwa Turanci). Ibadan and Zaria (Nigeria): University Press.

Newman, Roxana Ma. 1990. An English-Hausa Dictionary. New Haven: Yale University Press. (2nd ed., Ikeja (Nigeria): Longman (1997).)

NORLA. 1957. Hanyar Tadi da Turanci: A Dictionary of English Conversation for Hausa Students. Zaria (Nigeria): NORLA, London: Longmans, Green and Co.

Olderogge, Dmitrii A. 1963. Xausa-russkij slovar' (Hausa-Russian Dictionary). Moscow: GIS.

Parsons, Allan C. 1915. A Hausa Phrase Book with Medical and Scientific Vocabularies. Oxford: Humphrey Milford, OUP.

Robinson, Charles H. 1899/1900. Dictionary of the Hausa Language. Cambridge: Cambridge University Press. Vol. 1 Hausa-English (1899); Vol. 2 English-Hausa (1900). (2nd ed. 1906, with additions on interleaved pages, numbered 1a, 2a, etc., plus list of plants with Hausa names provided by J. M. Dalziel (added at end, numbered 1-8); 3rd ed., 2 vols., 1913; 4th ed., 2 vols., 1925 (reprinted by Gregg International Publishers, 1969).)

Sakkwato, Bello Adamu. 1993. Kamus na Jugorafiyya (Geography Dictionary). Sokoto: The Author.

Schön, James Frederick. 1843. Vocabulary of the Haussa Language. Phrases, and Specimens of Translations, to which are prefixed, the Grammatical Elements of the Haussa Language. London: Church Missionary Society.

Schön, James Frederick. 1876. Dictionary of the Hausa Language, with appendixes of Hausa Literature. London: Church Missionary House.

Seidel, August. 1906. Die Haussasprache. / La langue haoussa. / The Hausa Language. Heidelberg: Julius Groos.

Skinner, Neil. 1959. Hausa-English Pocket Dictionary. Zaria: Longmans, Green and Co. (2nd ed. 1968).

Skinner, Neil. 1965. Kamus na Turanci da Hausa. Babban Ja-Gora ga Turanci (English-Hausa Dictionary. A Major Guide to English). Zaria (Nigeria): Gaskiya Corporation for the Hausa Language Board. (2nd ed. 1970, Zaria: NNPC; illustrated ed. 1978.)

Skinner, Neil. 1985. Hausa Lexical Expansion since 1930: A Supplement to Bargery's Dictionary. Madison: African Studies Program, University of Wisconsin. 
Skinner, Neil. 1996. Hausa Comparative Dictionary. (Westafrikanische Studien: Frankfurter Beiträge zur Sprach- und Kulturgeschichte, 11.) Cologne: Rüdiger Köppe.

Taylor, F.W. 1927. A Fulani-Hausa Vocabulary. Oxford: Clarendon Press.

Vischer, Hanns. 1936. Vocabulary of Nigerian Names of Trees, Shrubs and Herbs. Lagos: Government Printer.

\section{B. Other works cited}

Abraham, R.C. 1934. The Principles of Hausa. Kaduna (Nigeria): Government Printer.

Abraham, R.C. 1959. The Language of the Hausa People. London: University of London Press.

Abu-Manga, Al-Amin. 1999. Hausa in the Sudan: Process of Adaptation to Arabic. Cologne: Rüdiger Köppe.

Baldi, Sergio. 1977. Systematic Hausa Bibliography. (Istituto Italo-Africano. Collana di Studi Africani 3.) Rome: Tip. Pioda.

Barth, Heinrich. 1862-1866. Collection of Vocabularies of Central-African Languages. / Sammlung und Bearbeitung zentralafrikanischer Vokabularien. Gotha: Justus Perthes.

Green, M.M. 1967. G.P. Bargery (1876-1966). Journal of West African Languages 4(2): 59-60.

Hair, P.E.H. 1967. The Early Study of Nigerian Languages: Essays and Bibliographies. (West African Language Monographs, 7.) Cambridge: Cambridge University Press. (Reprint with a new introduction by Paul Newman, Aldershot: Gregg, 1994.)

Jaggar, Philip J. 1992. Roy Clive Abraham: A Biographical Profile and List of Writings. Jaggar, P.J. (Ed.). 1992. Papers in Honour of R. C. Abraham (1890-1963): 1-4. (African Languages and Cultures, Supplement 1.) London: SOAS.

Kirk-Greene, A.H.M. 1964. The Hausa Language Board. Afrika und Übersee 47: 187-203.

Kirk-Greene, Anthony, and Paul Newman. 1971. West African Travels and Adventures: Two Autobiographical Narratives from Northern Nigeria. New Haven/London: Yale University Press.

Koelle, Sigismund W. 1854. Polyglotta Africana. London: Church Missionary Society. (Reprint with an historical introduction by P. E. H. Hair, Freetown: Fourah Bay College, 1963.)

Mischlich, Adam. 1902. Lehrbuch der hausanischen Sprache. (Archiv für das Studium der deutscher Kolonialsprachen, 1.) Berlin: Dietrich Reimer.

Newman, Paul. 1980a. The Classification of Chadic within Afroasiatic. Leiden: Universitaire Pers.

Newman, Paul. 1980b. The Two R's in Hausa. African Language Studies 17: 77-87.

Newman, Paul. 1996. Hausa and the Chadic Language Family: A Bibliography. (African Linguistic Bibliographies, 6.) Cologne: Rüdiger Köppe.

Newman, Paul. 2000. The Hausa Language: An Encyclopedic Reference Grammar. New Haven: Yale University Press.

Newman, Paul, and Roxana Ma Newman. 1991. Lexicography of the Chadic Languages. Hausmann, F. J. et al. (Eds.). 1991. Wörterbücher/Dictionaries/Dictionnaires, vol. 3: 2457-2460. Berlin: Walter de Gruyter.

Newman, Roxana Ma. 1974. Dictionaries of the Hausa Language. Harsunan Nijeriya 4: 1-25.

Newman, Roxana Ma. 1992. Lexicographic Method in R. C. Abraham's Hausa Dictionary. Jaggar, P.J. (Ed.). 1992. Papers in Honour of R. C. Abraham (1890-1963): 79-97. (African Languages and Cultures, Supplement 1.) London: SOAS.

Parsons, F.W. 1960. The Verbal System in Hausa. Afrika und Übersee 44: 1-36.

Taylor, F.W. 1923. A Practical Hausa Grammar. Oxford: Clarendon Press. (2nd ed. 1959.) 